\title{
Red blood cell transfusion in obstetrics and its implication for patient blood management: a retrospective analysis in Switzerland from 1998 to 2016
}

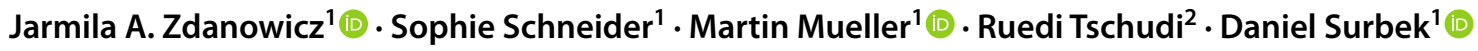

Received: 19 January 2020 / Accepted: 10 August 2020 / Published online: 19 August 2020

(c) The Author(s) 2020

\begin{abstract}
Purpose Peripartum hemorrhage (PPH) remains one of the main causes of maternal mortality worldwide. Treatment includes administration of packed red blood cells (RBC) in severe cases and patient blood management (PBM) may reduce it significantly. In our study, we wanted to retrospectively assess red blood cell administration in PPH to evaluate the impact of PBM in Switzerland.

Methods Using data from the Swiss obstetric hospital registry (Arbeitsgemeinschaft Schweizer Frauenkliniken, ASF), we included patients with deliveries from 1998 to 2016. We examined available obstetric data as well as blood loss and RBC administration in the acute and subacute peripartal phase. We categorized data into two time intervals: 1998-2011 and 2012-2016, as new PPH guidelines in Switzerland were established in 2012.

Results PPH incidence increased between 1998 and 2016 significantly. The number of vaginal instrumental deliveries and cesarean sections increased as well. Administration of three or more RBC units, as defined in the ASF registry, in the acute and subacute phase in Switzerland has decreased after 2012. Conversely, we saw an increase in the administration of one to two RBC units in the acute and subacute phase. Nevertheless, overall RBC administration has been decreasing from 1998 to 2016.

Conclusion The increase of patients obtaining one or two units of RBC for PPH suggests that there may be a potential for effective implication of PBM in obstetrics. Reduction of RBC transfusion in the context of PPH may not only decrease maternal morbidity, but decrease economic costs as well.
\end{abstract}

Keywords Patient blood management $\cdot$ Peripartum hemorrhage $\cdot$ Red blood cell $\cdot$ Transfusion

\section{Introduction}

Peripartum hemorrhage (PPH) remains one of the leading causes of maternal mortality worldwide, with an incidence of more than 15\% [1, 2]. According to the World Health Organization (WHO), PPH is defined as a blood loss of more than $500 \mathrm{ml}$ within $24 \mathrm{~h}$ after delivery [3]. In German-speaking countries, including Switzerland, Germany and Austria, PPH is defined as a blood loss of at least $500 \mathrm{ml}$ after vaginal

Daniel Surbek

daniel.surbek@insel.ch

1 Department of Obstetrics and Gynecology, Bern University Hospital, University of Bern, Theodor-Kocher-Haus,

Friedbühlstrasse 19, 3010 Bern, Switzerland

2 Sevisa AG, Ermatingen, Switzerland delivery and of at least $1000 \mathrm{ml}$ after Cesarean section (CS) [4].

Severe PPH usually requires the administration of red blood cell (RBC) transfusions. Yet, the administration of RBC itself has been shown to be associated with complications for the patient. Specific transfusion risks include transmission of infections, hemolytic transfusion reactions, transfusion-associated circulatory overload as well as transfusion-associated acute lung injury [5, 6]. But it can also lead to infections, ischemic events as well as multisystem organ failure [7]. In addition, several studies have shown that there are advantages to a restrictive use of RBC transfusions, including better clinical outcomes for patients, decreased morbidity and mortality, shorter hospitalization length and a lower risk for admission to the intensive care unit [7,8].

Not surprisingly, other medical professions such as trauma or cardiothoracic surgeons introduced guidelines 
for restrictive RBC administration, which is part of patient blood management (PBM). PBM is based on three pillars, aiming to (1) identify and treat anemia, (2) reduce blood loss and (3) reduce RBC administration [7, 9]. Several studies have shown that successful PBM leads to a quicker patient recovery and fewer postoperative complications [10-13]. To date, only few countries have implemented strategies for effective patient blood management in obstetrics.

In Western Australia, the PBM program has been implemented since 2008 and has shown to reduce hospital mortality, average hospital length of stay and hospital-acquired infections by one-fourth, respectively [14]. In 2015, PBM was developed specifically for the obstetric clinical practice [15].

The most common obstetric risk factors for PPH include placental pathologies (including abnormally invasive placenta, retrained placenta or placental abruption), previous $\mathrm{PPH}$, high maternal parity and pre-eclampsia, but also anemia and antepartum hemorrhage [4, 16, 17]. A further categorization of PPH can be made into primary or acute bleeding within $24 \mathrm{~h}$ of delivery, and secondary or subacute, which is bleeding after $24 \mathrm{~h}$ up to 12 weeks after delivery [18].

While some of the risk factors for PPH can be assessed during pregnancy and prior to delivery, up to two-thirds of women with a PPH have no known risk factors [19]. However, iron deficiency anemia can be assessed easily. In Switzerland, new guidelines for treating anemia in pregnancy were implemented in 2012 and recently updated [20]. Severe anemia in pregnancy is associated with fetal and maternal morbidities such as fetal growth restriction and preterm birth [21, 22]. In addition, anemia itself is a known risk factor for PPH.

Multiple obstetric guidelines exist for PPH management, while in Switzerland, Germany, and Austria an universal guideline for PPH treatment was introduced by obstetric societies [4]. One important update of those guidelines occurred in 2012, re-evaluating the application of conservative and surgical treatment of PPH, including RBC administration [23].

The aim of our study was to examine red blood cell transfusions in Switzerland over the last 18 years, using a large retrospectively database. Specifically, we studied the impact of new PPH guidelines on the administration of RBC.

\section{Materials and methods}

This was a retrospective database study using data from the Swiss obstetric hospital registry (Arbeitsgemeinschaft Schweizer Frauenkliniken, ASF) which is managed by Sevisa AG. This registry includes anonymized patient delivery and obstetric data from 40 obstetric hospitals, including primary, secondary and tertiary units, in Switzerland. Most hospitals included in this database are primary and secondary unit obstetric hospitals. Data are collected by physicians in each involved hospital and subsequently submitted and analyzed by Sevisa AG.

Patients who gave birth between January 1, 1998, and December 31, 2016, were included. We looked at RBC administration in the acute and subacute phase, blood loss, hemoglobin levels, potential PPH risk factors, need for postpartum intensive care unit (ICU) hospitalization, delivery mode and overall obstetric data. The amount of blood loss was determined at the discretion of each hospital (usually using visual estimates, weight of pads and surgical cloths, and surgical containers). Regarding RBC administration, we looked at overall RBC administration during hospitalization, as well as detailed data regarding administration of one or two RBC unit versus more three units or more (as used in the ASF data registry) in the acute and subacute phase during hospitalization after delivery.

Data were collected using administrative data. As new guidelines on PPH treatment were established in 2012 (as described above) and expected to be implemented by participating hospitals, we categorized data into two time intervals: 1998-2011 and 2012-2016. In addition, deliveries were categorized according to delivery mode: spontaneous vaginal birth, instrumental vaginal delivery and Cesarean section.

\section{Statistical analysis}

This analysis was based on annual reports from 1998 to 2016 that contained counts of categorical variables and means with standard deviation (SD) of continuous variables, hence on aggregated data. We pooled these data to achieve summary data for the two periods 1998-2011 and 2012-2016, respectively. To investigate whether these periods were different, we calculated pooled counts and \% of the categorical variables per period and compared the proportions by calculating odds ratios with $95 \%$ confidence intervals and exact $p$ values. We also calculated pooled means and SDs for maternal age, gestational age and neonatal weight und used $T$ tests to investigate differences. To assess whether there was a trend with respect to the absolute number of deliveries and relative number of different types of deliveries, we calculated Spearman's rho with corresponding $p$ value. All analyses were performed using Stata 14 (Stata Corp., College Station, Texas). A $p$ value $<0.05$ was considered significant.

\section{Results}

We included a total of 627,921 deliveries from 1998 to 2016. 
From 1998 to 2016, there was an increase in cesarean section as well as instrumental deliveries and a decrease in spontaneous vaginal delivery (Fig. 1).

From 1998 to $2011,454,463$ deliveries were included, while from 2012 to 2016173,458 deliveries were included. Peripartal data for both time intervals are summarized in Table 1.

Between the two time intervals 1998-2011 and 20122016, there was a significant increase in mean maternal age and required intensive care unit (ICU) visit, and a significant decrease in mean birth weight. In addition, there was an increase in potential risk factors for $\mathrm{PPH}$, including retained placental products, placenta previa, uterine rupture, previous cesarean sections, multiple gestation delivery, induction of labor, prolonged labor, polyhydramnios and amniotic infection syndrome. Interestingly, there was no difference in the incidence of abnormal placentation, including placenta accrete, increta or percreta. There was a significant increase in intraoperative blood loss and RBC administration of one to two units in the acute phase. In the subacute phase, there was a significant increase RBC administration of one to two units as well.

In the acute phase within $24 \mathrm{~h}$ after delivery, there was a decrease in the overall administration of RBC units as well as administration of three or more RBC units across all deliveries after 2012 (Fig. 2a). Instrumental vaginal delivery seems to be associated with an increased need for RBC administration (Fig. 2b).

In the subacute phase, there was a decrease of overall $\mathrm{RBC}$ administration as well as administration of three RBC units or more (Fig. 3a). In the subacute phase, instrumental vaginal delivery seems to be associated with an increased need for RBC administration as in the acute phase (Fig. 3b).

Overall, the number of three or more RBC units administered has decreased in both acute and subacute phase after 2012, while the number of one to two RBC units administered in the acute or subacute phase has increased after 2012. In addition, as can be seen in Figs. $2 \mathrm{a}$ and $3 \mathrm{a}$, instrumental delivery seems to be associated with peripartum hemorrhage and RBC administration in the acute and subacute phase.

\section{Discussion}

As has been previously described, there is a trend towards increasing PPH in the past 20 years in Switzerland, with an increase in vaginal instrumental deliveries and cesarean sections [24]. At the same time, our study shows that

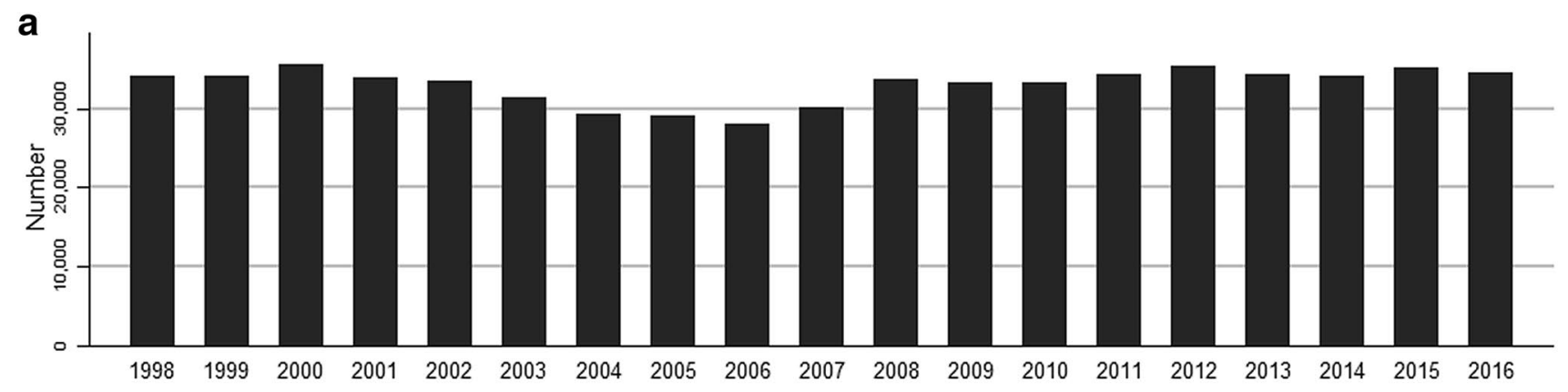

b

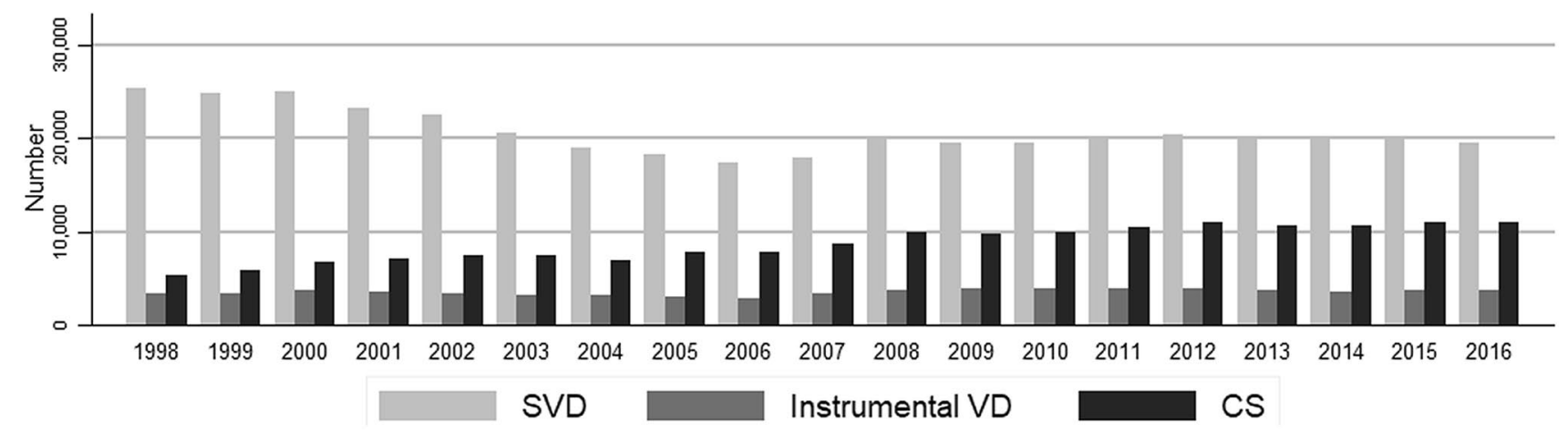

Fig. 1 a Total number of deliveries from 1998-2016; b deliveries from 1998-2016 according to delivery mode (SVD spontaneous vaginal delivery, Instrumental VD instrumental vaginal delivery, CS Cesarean section) 
Table 1 Comparison of peripartal outcome and risk factors for peripartum hemorrhage from 1998-2011 and 2012-2016 (SD standard deviation, $I C U$ intensive care unit, $R B C$ red blood cell, $H b$ hemoglobin)

\begin{tabular}{|c|c|c|c|c|}
\hline Total $N=627,921$ & $\begin{array}{l}1998-2011 \\
N=453,463\end{array}$ & $\begin{array}{l}2012-2016 \\
N=173,458\end{array}$ & Odds ratio $(95 \% \mathrm{CI})$ & $p$ value \\
\hline Mean maternal age (years) $\pm S D$ & $30.0 \pm 5.0$ & $31.0 \pm 4.9$ & & $<0.001$ \\
\hline Mean length of stay (days) & 5.4 & 4.6 & & \\
\hline Mean gestational age (weeks) \pm SD & $391 / 7 \pm 18$ days & $391 / 7 \pm 18$ days & & $<0.001$ \\
\hline Mean birth weight $(\mathrm{g}) \pm \mathrm{SD}$ & $3349 \pm 504$ & $3330 \pm 507$ & & $<0.001$ \\
\hline Required ICU visit & $1194(0.3 \%)$ & $676(0.4 \%)$ & $1.48(1.35-1.63)$ & $<0.001$ \\
\hline \multicolumn{5}{|l|}{ Peripartum (acute phase) } \\
\hline Intraoperative blood loss $500-1000 \mathrm{ml}$ & $40,842(9.0 \%)$ & $22,975(13.2 \%)$ & $1.54(1.52-1.57)$ & $<0.001$ \\
\hline Intraoperative blood loss $>1000 \mathrm{ml}$ & $5149(1.1 \%)$ & $3716(2.1 \%)$ & $1.91(1.83-1.99)$ & $<0.001$ \\
\hline \multicolumn{5}{|l|}{ Peripartum RBC units (acute) } \\
\hline Intraoperative $1-2 \mathrm{RBC}$ units & $913(0.2 \%)$ & $444(0.3 \%)$ & $1.27(1.13-1.43)$ & $<0.001$ \\
\hline Intraoperative $>2 \mathrm{RBC}$ units & $730(0.2 \%)$ & $250(0.1 \%)$ & $0.90(0.77-1.04)$ & 0.134 \\
\hline Postoperative $1-2 \mathrm{RBC}$ units & $880(0.2 \%)$ & $425(0.2 \%)$ & $1.26(1.12-1.42)$ & $<0.001$ \\
\hline Postoperative $>2$ RBC units & $558(0.1 \%)$ & $180(0.1 \%)$ & $0.84(0.71-1.00)$ & 0.048 \\
\hline \multicolumn{5}{|l|}{ Hospital stay after birth (subacute) } \\
\hline $\mathrm{Hb}<100 \mathrm{~g} / 1$ & $26,431(5.8 \%)$ & $5274(3.0 \%)$ & $0.51(0.49-0.52)$ & $<0.001$ \\
\hline \multicolumn{5}{|l|}{ RBC units (subacute) } \\
\hline $1-2$ RBC units & $1871(0.4 \%)$ & $953(0.5 \%)$ & $1.33(1.23-1.44)$ & $<0.001$ \\
\hline $3 \mathrm{RBC}$ units or more & $1184(0.3 \%)$ & $400(0.2 \%)$ & $0.88(0.79-0.99)$ & 0.033 \\
\hline \multicolumn{5}{|l|}{ Possible risk factors } \\
\hline Retained placental products & $8744(1.9 \%)$ & $4014(2.3 \%)$ & $1.20(1.16-1.25)$ & $<0.001$ \\
\hline Placenta previa & $1275(0.3 \%)$ & $654(0.4 \%)$ & $1.34(1.22-1.48)$ & $<0.001$ \\
\hline Uterine rupture & $129(0.0 \%)$ & $84(0.0 \%)$ & $1.70(1.28-2.26)$ & $<0.001$ \\
\hline Previous Cesarean section & $47,646(10.5 \%)$ & $24,409(14.1 \%)$ & $1.39(1.37-1.42)$ & $<0.001$ \\
\hline Multiple gestation delivery & $6208(1.4 \%)$ & $3100(1.8 \%)$ & $1.31(1.25-1.37)$ & $<0.001$ \\
\hline Induction of labor & $91,335(20.1 \%)$ & $36,864(21.3 \%)$ & $1.07(1.06-1.08)$ & $<0.001$ \\
\hline Prolonged labor & $27,181(6.0 \%)$ & $10,891(6.3 \%)$ & $1.05(1.03-1.08)$ & $<0.001$ \\
\hline Polyhydramnios & $2689(0.6 \%)$ & $1698(1.0 \%)$ & $1.66(1.56-1.76)$ & $<0.001$ \\
\hline Amniotic infection syndrome & $1026(0.2 \%)$ & $521(0.3 \%)$ & $1.33(1.19-1.48)$ & $<0.001$ \\
\hline Primary uterine inertia & $135,248(29.8 \%)$ & $46,106(26.6 \%)$ & $0.85(0.84-0.86)$ & $<0.001$ \\
\hline Placenta accreta/increta/percreta & $1558(0.3 \%)$ & $593(0.3 \%)$ & $1.00(0.90-1.10)$ & 0.942 \\
\hline Placental abruption & $1315(0.3 \%)$ & $464(0.3 \%)$ & $0.92(0.83-1.03)$ & 0.137 \\
\hline Pre-eclampsia & $5673(1.3 \%)$ & $2310(1.3 \%)$ & $1.07(1.01-1.12)$ & 0.011 \\
\hline Low-lying placenta & $1635(0.4 \%)$ & $648(0.4 \%)$ & $1.04(0.94-1.14)$ & 0.439 \\
\hline
\end{tabular}

despite this increase, excessive RBC administration in the acute and subacute phase in Switzerland has been decreasing after 2012. This is in line with the implementation of Swiss guidelines on PPH and anemia in pregnancy $[4,20$, 23]. Nevertheless, there was an increase in the administration of one to two RBC units. Our study has also shown that there has been an increase in risk factors over the years. However, as the majority of women have no known risk factors for $\mathrm{PPH}$, a guideline for patient blood management should be in place which would potentially reduce even low RBC administration. For example, anemia is a major risk factor for PPH [25]. Current Swiss guidelines recommend regular screening of hemoglobin levels at least once per trimester as well as to screen for iron levels in the first trimester [20]. This is one step towards an effective patient blood management.

Yet, recently there has been more focus on acute treatment of PPH with increased early use of tranexamic acid. Several studies have already shown and currently further studies are ongoing about the effective use of tranexamic acid as a first-line therapy or even prophylactic use for PPH [17, 26-29]. Other studies have indicated that the administration of carbetocin as well as oxytocin can effectively prevent PPH after vaginal delivery [30, 31]. In addition, cell saver, which uses allogenic blood, might also benefit women with an increased risk for PPH [32]. 


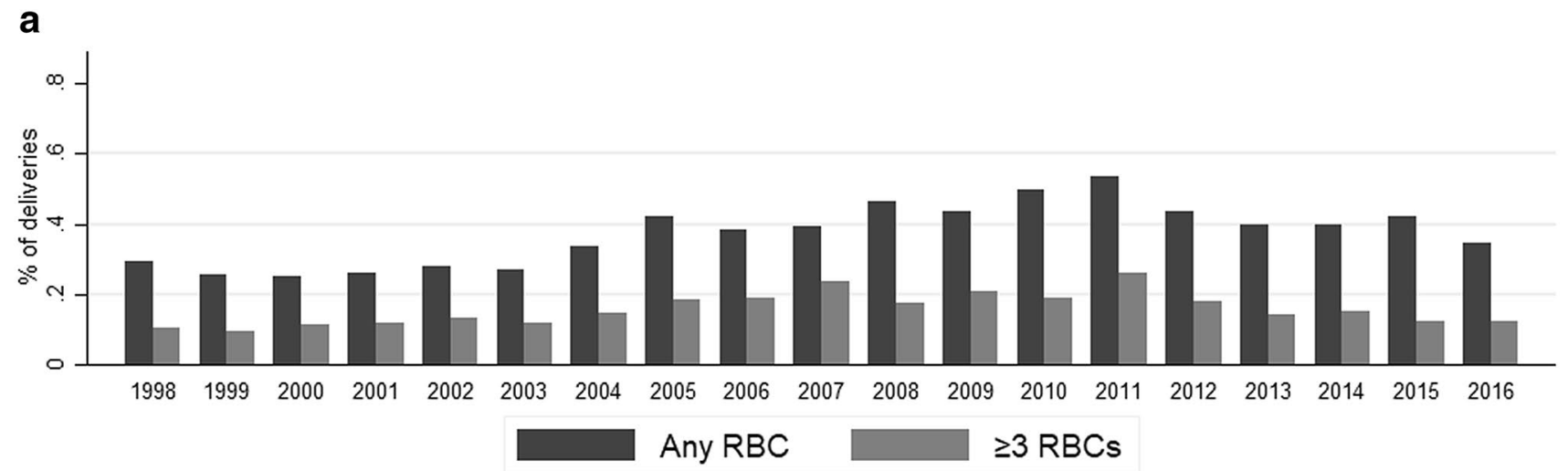

b

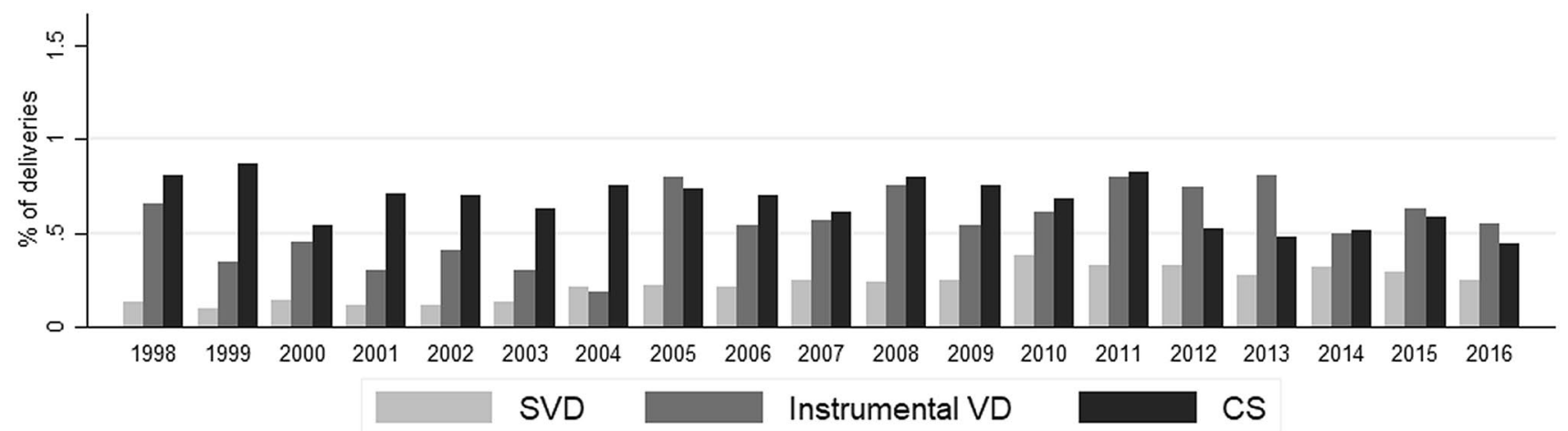

Fig. 2 a RBC administration in the acute phase from 1998-2016 across all deliveries; $\mathbf{b}$ overall RBC administration in the acute phase from 1998-2016 across individual delivery modes ( $R B C$ red blood

cell, SVD spontaneous vaginal delivery, Instrumental VD instrumental vaginal delivery, $C S$ Cesarean section)

The strength of our study is its large sample size, the large time interval of 18 years and the inclusion of 40 hospitals. One weakness of our study is its retrospective character; however, due to the large sample size possibly misrecorded data should be largely counterbalanced. In addition, the two time intervals we chose were not equal in length, the interval from 2012 to 2016 only encompassing five years. Furthermore, as data for the registry is usually collected before placental histology becomes available, this might have been insufficiently recorded on data sheets. In addition, we refrained from calculating a multivariate analysis to investigate possible interactions of risk factors based on our aggregated data as results would not be interpretable because of associations between variables due to ecological fallacy.

Overall, our study shows that there is still a need for providing and optimizing PBM in obstetrics. Common guidelines need to be established to effectively prevent PPH in obstetrics. This might include a standardized questionnaire for PPH risk factors in a prenatal screening, autologous transfusion and, as already mentioned, prophylactic administration of tranexamic acid. PBM is profitable from an economic point of view as well. It is associated with lower hospitalization costs, lower transfusion costs as well as lower in-patient costs.

Currently, PBM in obstetrics and its impact on maternal and perinatal morbidity and mortality is understudied. Furthermore, awareness of PBM in obstetrical units is low, suggesting a great potential for improving the grade of implementation of PBM with a beneficial medical and economic impact. 

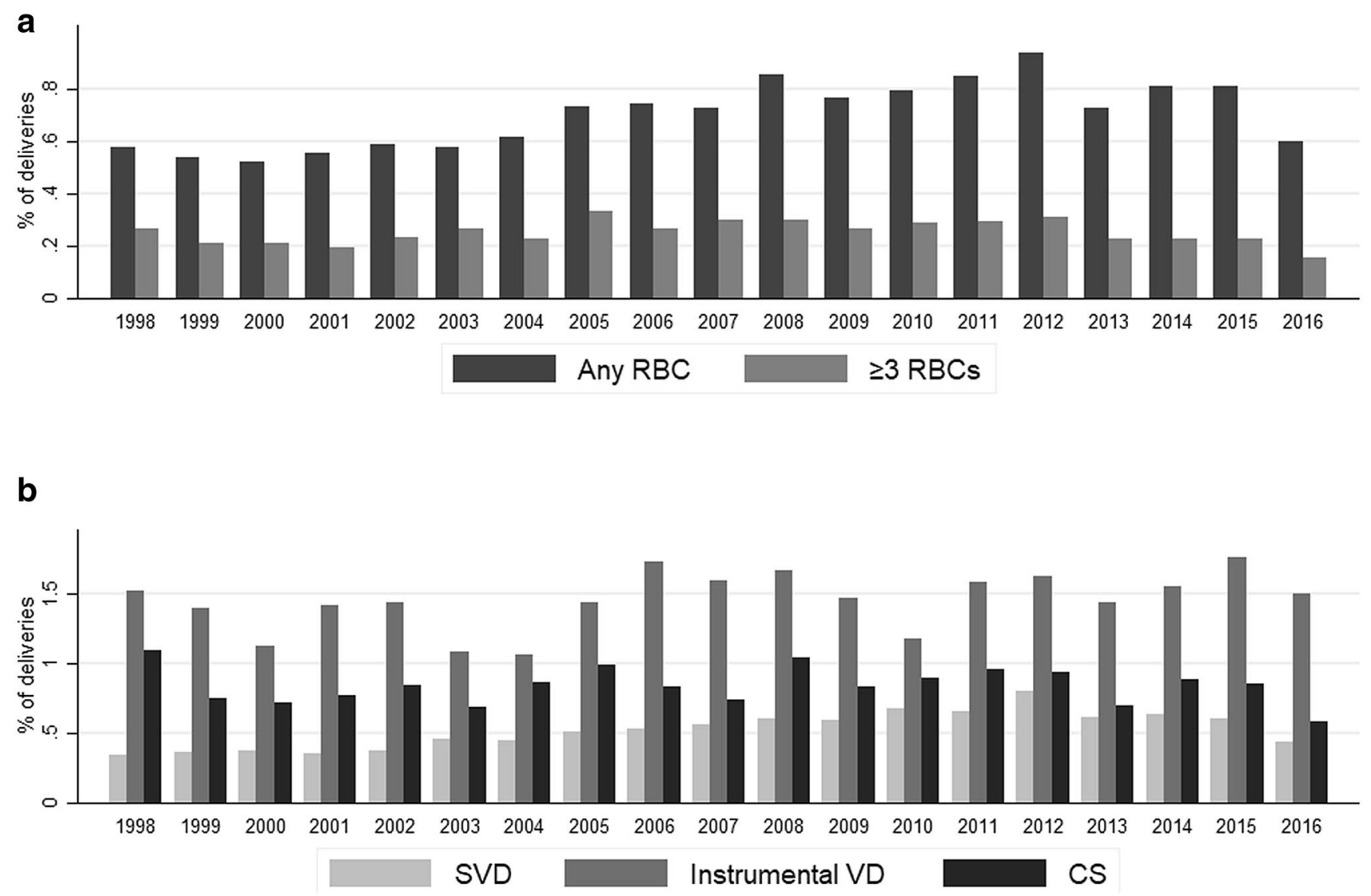

Fig. 3 a RBC administration in the subacute phase from 1998-2016 across all deliveries; $\mathbf{b}$ overall RBC administration in the subacute phase from 1998-2016 across individual delivery modes ( $R B C$

Author contributions JAZ: protocol/project development; data collection or management; data analysis; manuscript writing/editing. SS: manuscript writing/editing. MM: manuscript writing/editing. RT: data collection or management. DS: protocol/project development; data analysis; manuscript writing/editing.

Acknowledgements Open access funding provided by University of Bern. This study has been supported by an unrestricted Grant from VIFOR Co. as an investigator-initiated study.

\section{Compliance with ethical standards}

Conflict of interest The authors declare that they have no conflict of interest.

Ethical approval All procedures performed in studies involving human participants were in accordance with the ethical standards of the institutional and/or national research committee and with the 1964 Helsinki declaration and its later amendments or comparable ethical standards. For this type of study, formal consent is not required.

Human and animal rights statement This article does not contain any studies with animals performed by any of the authors. red blood cell, SVD spontaneous vaginal delivery, Instrumental VD instrumental vaginal delivery, CS Cesarean section)

Open Access This article is licensed under a Creative Commons Attribution 4.0 International License, which permits use, sharing, adaptation, distribution and reproduction in any medium or format, as long as you give appropriate credit to the original author(s) and the source, provide a link to the Creative Commons licence, and indicate if changes were made. The images or other third party material in this article are included in the article's Creative Commons licence, unless indicated otherwise in a credit line to the material. If material is not included in the article's Creative Commons licence and your intended use is not permitted by statutory regulation or exceeds the permitted use, you will need to obtain permission directly from the copyright holder. To view a copy of this licence, visit http://creativecommons.org/licenses/by/4.0/.

\section{References}

1. Bhutta ZA, Black RE (2013) Global maternal, newborn, and child health—so near and yet so far. N Engl J Med 369(23):2226-2235. https://doi.org/10.1056/NEJMra1111853

2. Say L, Chou D, Gemmill A, Tuncalp O, Moller AB, Daniels J, Gulmezoglu AM, Temmerman M, Alkema L (2014) Global causes of maternal death: a WHO systematic analysis. Lancet Glob Health 2(6):e323-333. https://doi.org/10.1016/s2214 $-109 x(14) 70227-x$ 
3. Tuncalp O, Souza JP, Gulmezoglu M (2013) New WHO recommendations on prevention and treatment of postpartum hemorrhage. Int J Gynaecol Obstet 123(3):254-256. https://doi. org/10.1016/j.ijgo.2013.06.024

4. Schlembach D, Helmer H, Henrich W, von Heymann C, Kainer F, Korte W, Kuhnert M, Lier H, Maul H, Rath W, Steppat S, Surbek D, Wacker J (2018) Peripartum haemorrhage, diagnosis and therapy. Guideline of the DGGG, OEGGG and SGGG (S2k Level, AWMF Registry No. 015/063, March 2016). Geburtshilfe Frauenheilkd 78(4):382-399. https://doi.org/10.1055/a-0582-0122

5. Munoz M, Pena-Rosas JP, Robinson S, Milman N, Holzgreve W, Breymann C, Goffinet F, Nizard J, Christory F, Samama CM, Hardy JF (2018) Patient blood management in obstetrics: management of anaemia and haematinic deficiencies in pregnancy and in the post-partum period: NATA consensus statement. Transfus Med 28(1):22-39. https://doi.org/10.1111/tme.12443

6. Waters JH (2014) Patient blood management in obstetrics. Int Anesthesiol Clin 52(3):85-100. https://doi.org/10.1097/aia.00000 00000000015

7. Isbister JP (2013) The three-pillar matrix of patient blood management-an overview. Best Pract Res Clin Anaesthesiol 27(1):69-84. https://doi.org/10.1016/j.bpa.2013.02.002

8. Murphy GJ, Reeves BC, Rogers CA, Rizvi SI, Culliford L, Angelini GD (2007) Increased mortality, postoperative morbidity, and cost after red blood cell transfusion in patients having cardiac surgery. Circulation 116(22):2544-2552. https://doi.org/10.1161/ circulationaha.107.698977

9. Gombotz H (2012) Patient blood management: a patient-orientated approach to blood replacement with the goal of reducing anemia, blood loss and the need for blood transfusion in elective surgery. Transfus Med Hemother 39(2):67-72. https://doi.org/10.1159/000337183

10. Theusinger OM, Kind SL, Seifert B, Borgeat L, Gerber C, Spahn DR (2014) Patient blood management in orthopaedic surgery: a fouryear follow-up of transfusion requirements and blood loss from 2008 to 2011 at the Balgrist University Hospital in Zurich. Switzerland. Blood Transf 12(2):195-203. https://doi.org/10.2450/2014.0306-13

11. Dhir A, Tempe DK (2018) Anemia and patient blood management in cardiac surgery-literature review and current evidence. J Cardiothorac Vasc Anesth 32(6):2726-2742. https://doi.org/10.1053/j. jvca.2017.11.043

12. Meybohm P, Herrmann E, Steinbicker AU, Wittmann M, Gruenewald M, Fischer D, Baumgarten G, Renner J, Van Aken HK, Weber CF, Mueller MM, Geisen C, Rey J, Bon D, Hintereder G, Choorapoikayil S, Oldenburg J, Brockmann C, Geissler RG, Seifried E, Zacharowski K (2016) Patient blood management is associated with a substantial reduction of red blood cell utilization and safe for patient's outcome: a prospective, multicenter cohort study with a noninferiority design. Ann Surg 264(2):203-211. https://doi. org/10.1097/sla.0000000000001747

13. Meybohm P, Froessler B, Goodnough LT, Klein AA, Munoz M, Murphy MF, Richards T, Shander A, Spahn DR, Zacharowski K (2017) Simplified international recommendations for the implementation of patient blood management (SIR4PBM). Perioper Med (London, England) 6:5. https://doi.org/10.1186/s13741-017-0061-8

14. Leahy MF, Hofmann A, Towler S, Trentino KM, Burrows SA, Swain SG, Hamdorf J, Gallagher T, Koay A, Geelhoed GC, Farmer SL (2017) Improved outcomes and reduced costs associated with a health-system-wide patient blood management program: a retrospective observational study in four major adult tertiary-care hospitals. Transfusion 57(6):1347-1358. https://doi.org/10.1111/trf.14006

15. Australia NBA (2015) Patient blood management guidelines: Module 5 obstetrics and maternity. National Blood Authority Australia. https://www.blood.gov.au/pbm-module-5. 25.11.2018

16. Bateman BT, Berman MF, Riley LE, Leffert LR (2010) The epidemiology of postpartum hemorrhage in a large, nationwide sample of deliveries. Anesth Analg 110(5):1368-1373. https://doi. org/10.1213/ANE.0b013e3181d74898

17. Lier H, von Heymann C, Korte W, Schlembach D (2018) Peripartum haemorrhage: haemostatic aspects of the new German PPH guideline. Transf Med Hemother 45(2):127-135. https://doi. org/10.1159/000478106

18. (2006) ACOG Practice Bulletin: clinical management guidelines for obstetrician-gynecologists Number 76, October 2006: postpartum hemorrhage. Obstet Gynecol 108(4):1039-1047

19. Abdul-Kadir R, McLintock C, Ducloy AS, El-Refaey H, England A, Federici AB, Grotegut CA, Halimeh S, Herman JH, Hofer S, James AH, Kouides PA, Paidas MJ, Peyvandi F, Winikoff R (2014) Evaluation and management of postpartum hemorrhage: consensus from an international expert panel. Transfusion 54(7):1756-1768. https://doi.org/10.1111/trf.12550

20. Breymann C, Honegger C, Hosli I, Surbek D (2017) Diagnosis and treatment of iron-deficiency anaemia in pregnancy and postpartum. Arch Gynecol Obstet 296(6):1229-1234. https://doi.org/10.1007/ s00404-017-4526-2

21. Stevens GA, Finucane MM, De-Regil LM, Paciorek CJ, Flaxman SR, Branca F, Pena-Rosas JP, Bhutta ZA, Ezzati M (2013) Global, regional, and national trends in haemoglobin concentration and prevalence of total and severe anaemia in children and pregnant and non-pregnant women for 1995-2011: a systematic analysis of population-representative data. Lancet Global health 1(1):e16-25. https://doi.org/10.1016/s2214-109x(13)70001-9

22. Haider BA, Olofin I, Wang M, Spiegelman D, Ezzati M, Fawzi WW (2013) Anaemia, prenatal iron use, and risk of adverse pregnancy outcomes: systematic review and meta-analysis. BMJ (Clini Res Ed) 346:f3443. https://doi.org/10.1136/bmj.f3443

23. Schlembach D, Mortl MG, Girard T, Arzt W, Beinder E, Brezinka C, Chalubinski K, Fries D, Gogarten W, Hackeloer BJ, Helmer H, Henrich W, Hosli I, Husslein P, Kainer F, Lang U, Pfanner G, Rath W, Schleussner E, Steiner H, Surbek D, Zimmermann R (2014) Management of postpartum hemorrhage (PPH): algorithm of the interdisciplinary D-A-CH consensus group PPH (Germany-AustriaSwitzerland). Der Anaesth 63(3):234-242. https://doi.org/10.1007/ s00101-014-2291-1

24. Kaelin Agten A, Passweg D, von Orelli S, Ringel N, Tschudi R, Tutschek B (2017) Temporal trends of postpartum haemorrhage in Switzerland: a 22-year retrospective population-based cohort study. Swiss Med Wkly 147:w14551. https://doi.org/10.4414/ smw.2017.14551

25. Al-Zirqi I, Vangen S, Forsen L, Stray-Pedersen B (2008) Prevalence and risk factors of severe obstetric haemorrhage. BJOG Int J Obstet Gynaecol 115(10):1265-1272. https://doi.org/10.111 $1 /$ j.1471-0528.2008.01859.x

26. Della Corte L, Saccone G, Locci M, Carbone L, Raffone A, Giampaolino P, Ciardulli A, Berghella V, Zullo F (2018) Tranexamic acid for treatment of primary postpartum hemorrhage after vaginal delivery: a systematic review and meta-analysis of randomized controlled trials. J Matern Fetal Neonatal Med. https://doi.org/10.1080/14767 058.2018.1500544

27. Saccone G, Della Corte L, D’Alessandro P, Ardino B, Carbone L, Raffone A, Guida M, Locci M, Zullo F, Berghella V (2019) Prophylactic use of tranexamic acid after vaginal delivery reduces the risk of primary postpartum hemorrhage. J Matern Fetal Neonatal Med. https://doi.org/10.1080/14767058.2019.1571576

28. Ahmadzia HK, Phillips JM, Katler QS, James AH (2018) Tranexamic acid for prevention and treatment of postpartum hemorrhage: an update on management and clinical outcomes. Obstet Gynecol Surv 73(10):587-594. https://doi.org/10.1097/ogx.00000 00000000597

29. (2017) Effect of early tranexamic acid administration on mortality, hysterectomy, and other morbidities in women with postpartum haemorrhage (WOMAN): an international, randomised, 
double-blind, placebo-controlled trial. Lancet (London, England) 389(10084):2105-2116. https://doi.org/10.1016/s0140 -6736(17)30638-4

30. Widmer M, Piaggio G, Nguyen TMH, Osoti A, Owa OO, Misra S, Coomarasamy A, Abdel-Aleem H, Mallapur AA, Qureshi Z, Lumbiganon P, Patel AB, Carroli G, Fawole B, Goudar SS, Pujar YV, Neilson J, Hofmeyr GJ, Su LL, Ferreira de Carvalho J, Pandey U, Mugerwa K, Shiragur SS, Byamugisha J, Giordano D, Gulmezoglu AM (2018) Heat-stable carbetocin versus oxytocin to prevent hemorrhage after vaginal birth. N Engl J Med 379(8):743-752. https:// doi.org/10.1056/NEJMoa1805489

31. Gallos ID, Papadopoulou A, Man R, Athanasopoulos N, Tobias A, Price MJ, Williams MJ, Diaz V, Pasquale J, Chamillard M, Widmer M, Tuncalp O, Hofmeyr GJ, Althabe F, Gulmezoglu AM, Vogel JP,
Oladapo OT, Coomarasamy A (2018) Uterotonic agents for preventing postpartum haemorrhage: a network meta-analysis. Cochrane Database Syst Rev 12:cd011689. https://doi.org/10.1002/14651858. CD011689.pub3

32. Lew E, Tagore $\mathbf{S}$ (2015) Implementation of an obstetric cell salvage service in a tertiary women's hospital. Singapore Med J 56(8):445449. https://doi.org/10.11622/smedj.2015121

Publisher's Note Springer Nature remains neutral with regard to jurisdictional claims in published maps and institutional affiliations. 